\title{
複合改良地盤材を用いた戸建住 SEISMIC RESPONSE REDUCTION 宅の地震応答低減 OF A HOUSE WITH IMPROVED COMPOSITE SOIL MATERIAL
}

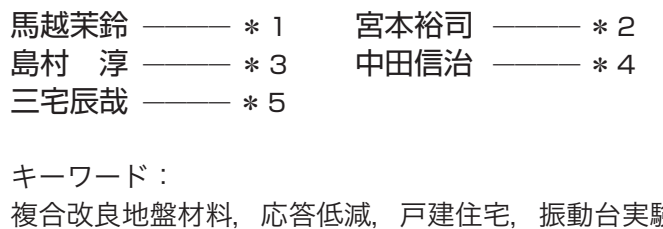

Keywords:

Improved composite soil material, Response reduction, Detached house, Shaking table test

\section{Marin UMAKOSHI- $* 1$ \\ Atsushi SHIMAMURA $-* 3$ \\ Tatsuya MIYAKE}

This paper addresses the developing of response reduction device of a detached house during earthquake. Reduction devices are composed of shear key and improved composite soil material, which are arranged between the seismic-isolated layers. The mechanical properties of the improved composite soil material are investigated by laboratory tests. Then we confirm the hysteresis characteristics of this system by shaking table tests. Furthermore we investigate the response reduction effects of a house with this device during earthquake by analytical studies.

\section{1.はじめに}

最近の被害地震では想定を上回る地震動が観測され、多くの戸建 住宅が被害を受けている。そのため、地震対策で考える入力地震動 を最大級のものにして、耐震性を確認する必要性が高まっている。

戸建住宅の地震被害を低減させる方法として、免震構造が効果を 発揮することはこれまでの地震において確認されてきたが 1),2)、長 周期地震動や大振幅パルス地震動の入力によって、積層ゴムやす心゙ り支承に過大な変形が生じる ${ }^{3)}$ 5)。また、各種ダンパーを用いて地 震応答を低減する制震構造も採用されるが、極大地震に対して効果 を期待するためにはかなりの数量のダンパーが必要となる。

本研究では、戸建住宅の地震被害を低減する装置として、勒性の ある複合改良地盤材料（以下「複合地盤材」と称する）の塑性化によ る抵抗特性によって、上部構造の加速度応答や変位応答を抑える機 構の開発を目指す。複合地盤材は、セメントにゴムチップと繊維材 を混合した安価なもので、ゴムチップの添加による変形性能の向上 に加え、繊維材の添加により高勒性の性能をもつものである 6),7)。 複合地盤材を用いた応答低減装置は、シアキーによって上部構造か らの水平力が伝達される。また、過大な変形に対しても、複合材料 の配合割合や装置の個数を調整することによって対応できる利点が ある。

本論文では、振動台を用いて複合地盤材を用いた応答低減装置の 性能実験を行い、得られた抵抗特性を取り入れたモデルで戸建住宅 の地震応答解析を行う。入力地震動としては、通常のレベル 2 相当 の設計用地震動と、それを超える最近観測された強震動を用いて行 い、上部構造の加速度や層間変位の応答低減効果について分析し、 この装置の適用性と有効性を検討する。

\section{2. 大型振動台による複合地盤材の性能実験}

\section{1. 試験体の概要}

試験体は、3050mm 四方の鉄骨基礎梁の上に重量 $4.64 \mathrm{kN}$ の付加 錘 16 枚を均等に配置し緊結したものである。基礎梁の四隅下部は、 振動台上に設置したすべり支承（公称摩擦係数 $\mu: 0.046 ） に$ 載せて おり、すべり板上をすべる。試験体の総重量は $86.8 \mathrm{kN}$ であり、後 述する複合地盤材装置も含めた試験体の総重量は約 $87.5 \mathrm{kN}$ である。 図 1 に試験体概要図を示す。

\section{2. 応答低減装置}

複合地盤材の装置は、鉄板上の幅 $1680 \mathrm{~mm}$ 、奥行 $600 \mathrm{~mm}$ 、高さ $200 \mathrm{~mm}$ の鉄製型枠の中心にシアキーを設置し、型枠内に複合材料 を充填させた。シアキーは、付加錘と基礎梁のせん断力を伝達する ものであり、直径 $\varphi 216.3 \mathrm{~mm}$ 、厚み $8.15 \mathrm{~mm}$ の円形鋼管にグラウト モルタルを注入した。シアキー底面と型枠底面間に摩擦力を生じさ せないよう $20 \mathrm{~mm}$ の隙間を設けた。この応答低減装置を、試験体の 中央部となるように振動台上に固定し、シアキーを基礎梁と接続さ せた。図 2 に応答低減装置の平面図を、図 3 にシアキー概要を示す。

複合地盤材は、従来用いられているセメント系改良地盤に剛性と 変形性能を調整するゴムチップと、勒性をもたすための長さ $30 \mathrm{~mm}$ の短繊維材を加えたものである。泥土は建設発生土で、これに加水 および砂分調整を行い、一般的な固化処理土で用いられている性状 と一致させた。ゴムチップは廃タイヤゴムを 1 \% $3 \mathrm{~mm}$ に粉砕したも のを用いた。その使用材料を表 1 に、配合を表 2 に示寸。図 4 に一 軸圧縮試験結果より得られた応力ーひずみ関係を示す。試験は表 2 に示した配合について、材齢 28 日の水中養生を行った円柱供試体 を用いて実施した。これより、ひずみが 10\%を超えても強度を維持

本稿は 2014 年度日本建築学会大会にて発表した内容（参考文献 8) に、新たな結果と考察を加えて再構成したものである。

大阪大学大学院丁学研究科地球総合丁学専攻建築丁学部門 大学院生 ( ₹ 565-0871 大阪府吹田市山田丘 2-1)

大阪大学大学院工学研究科地球総合工学専攻建築工学部門 教授・博士 (工学) Graduate School of Eng., Osaka Univ.

ケミカルグラウト(株) 博士（工学）

旭化成ホームズ(株住宅総合技術研究所 博士（工学)

(株)日本システム設計 代表取締役・博士（工学）

Prof., Dept. of Architectural Eng., Div. of Global Architecture, Graduate School of Eng., Osaka Univ., Dr. Eng.

3 Chemical Grouting Co., Dr. Eng.

4 R \& D Laboratories, Asahi Kasei Homes Corporation, Dr. Eng.

5 President, Nihon System Sekkei Architects \& Engineers, Dr. Eng. 
しており、勒性的な性状を示すことが確認できる。複合地盤材を打 設後の応答低減装置を写真 1 に示寸。

\section{3. 計測器と入力波}

振動台実験での計測は、図 1 に示したように応答低減装置の複合 地盤材上、振動台上、付加錘上に加速度計を配置した。さらに、振 動台と基礎梁、応答低減装置とシアキーの相対変位を計測した。振 動台入力波は、周期 $1.0 \mathrm{~s}$ で、最大振幅 $10 \mathrm{~mm} 、 30 \mathrm{~mm} 、 50 \mathrm{~mm} 、 80 \mathrm{~mm}$ 、 $100 \mathrm{~mm}$ の正弦波を連続して入力した。図 5 に振動台上で計測され た入力変位波形を示す。

\section{3. 実験結果}

\section{1. すべり支承の特性確認実験}

すべり支承の摩擦と履歴特性を確認するために、本実験に先立ち すべり支承と積層ゴムを配置した試験体で加振実験を行った。正弦 波(最大振幅 $50 \mathrm{~mm}$ 、周期 $1 \mathrm{~s}$ ) を入力した際の、すべり支承の抵抗特 性であるせん断力 $Q$-変位 $d$ の関係を図 6 に示寸。せん断力 $Q$ は、 付加錘と基礎梁の総重量に付加錘上に設置した加速度計の計測加速 度を掛けて求め、変位 $d$ は振動台と基礎梁の相対変位計の計測結果 である。この結果より摩擦係数を算定し、0.08 という值を得た。

\section{2. 応答低減装置を用いた加振実験結果}

積層ゴムの代わりに、シアキーを複合地盤材に埋め込んだ応答低 減装置を取り付けた試験体の加振実験から求めた、せん断力 $Q$-変 位 $d$ の関係を図 7 に示す。この図は、複合地盤材とすべり支承を合 わせたせん断力 $Q$ 一変位 $d$ の関係である。

実験結果より、小振幅の入力では複合地盤材の装置の抵抗剛性は ほぼ弾性的な性状を示し、降伏後は緩やかな曲線を描きながら降伏 荷重に達することがわかる。これは、押し込まれた複合材料の剛性 と鞋性、さらに応答低減装置の外周枠の拘束が影響して試験体のせ ん断力に抵抗するためである。また、複合地盤材は繰り返し押し込 まれて剛性が低下するが、安定して振動エネルギーを吸収している。 また、変位が $5 \mathrm{~cm}$ を超えると塑性変位が大きくなるが、これは繰り 返し回数が多くなるにつれてシアキーと複合材料の間にすき間が生 じているためである。

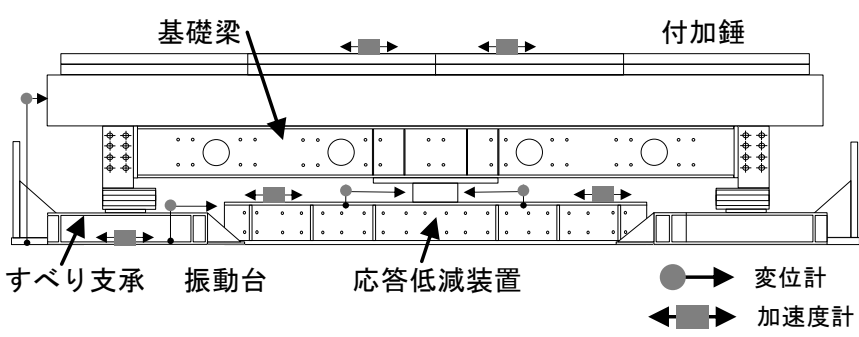

図 1 試験体概要図と計測器配置図

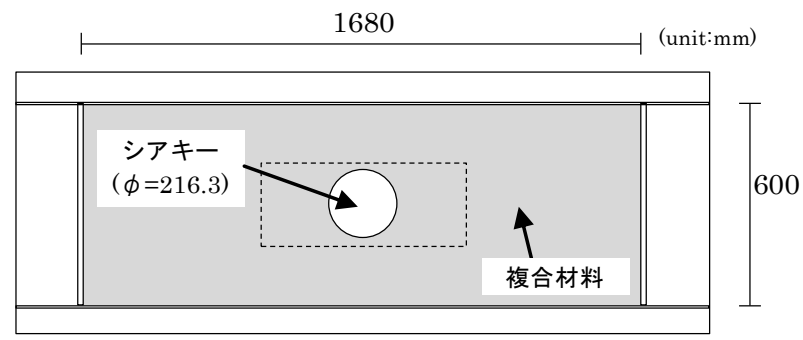

図 2 応答低減装置の平面図

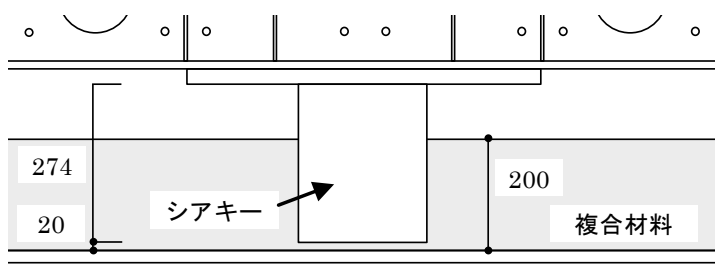

図 3 シアキー概要

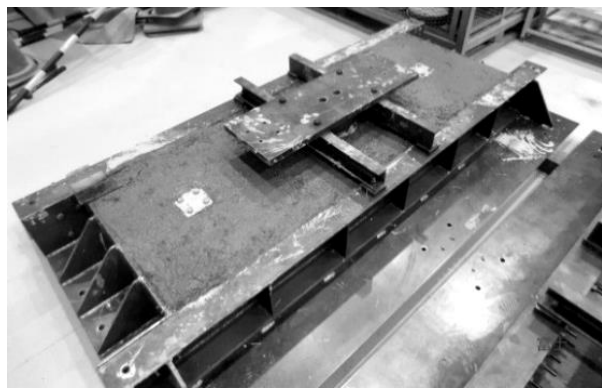

写真 1 複合地盤材を用いた応答低減装置

表 1 複合地盤材に使用した材料

\begin{tabular}{|c|c|}
\hline 材料 & 性状 \\
\hline セメント & $\begin{array}{l}\text { 早強ポルトランドセメント } \\
\text { 密度 }=3.14 \mathrm{~g} / \mathrm{cm}^{3}\end{array}$ \\
\hline 泥土 & $\begin{array}{l}\text { 現場発生土 }+ \text { 加水 }(\text { 含水比 } 87.5 \% \text { 程度 }) \\
\text { 密度 }=1.50 \pm 0.02 \mathrm{~g} / \mathrm{cm}^{3} \\
\text { 砂分率 }=40 \pm 2.5 \% \\
\text { スランプフロー值 }=400 \pm 50 \mathrm{~mm}\end{array}$ \\
\hline ゴムチップ & $\begin{array}{l}\text { 廃タイヤゴムチップ } \\
\text { 密度 }=1.10 \mathrm{~g} / \mathrm{cm}^{3} \\
\text { 粒径 }=1 \sim 3 \mathrm{~mm}\end{array}$ \\
\hline 繊維材 & $\begin{array}{l}\text { ポリプロピレン短繊維 } \\
\text { 平均径 }=\text { 約 } 0.75 \mathrm{~mm} \\
\text { 長さ }=30 \mathrm{~mm}\end{array}$ \\
\hline
\end{tabular}

表 2 複合地盤材の配合

\begin{tabular}{|c|c|c|}
\hline $\begin{array}{c}\text { セメント } \\
\left(\mathrm{kg} / \mathrm{m}^{3}\right)\end{array}$ & $\begin{array}{c}\text { 廃タイヤゴムチップ } \\
\left(\mathrm{kg} / \mathrm{m}^{3}\right)\end{array}$ & $\begin{array}{c}\text { 繊維材 } \\
(\text { 体積比\%) }\end{array}$ \\
\hline 150 & 300 & 5 \\
\hline
\end{tabular}

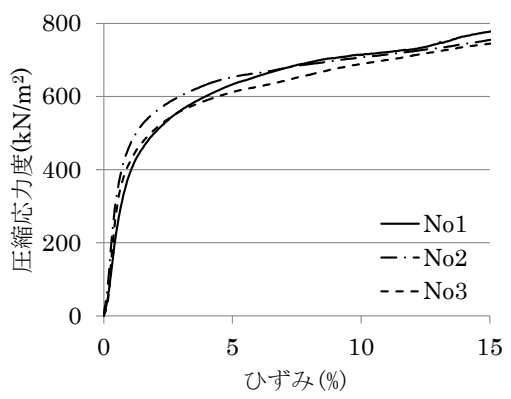

図 4 複合地盤材の一軸圧縮試験結果

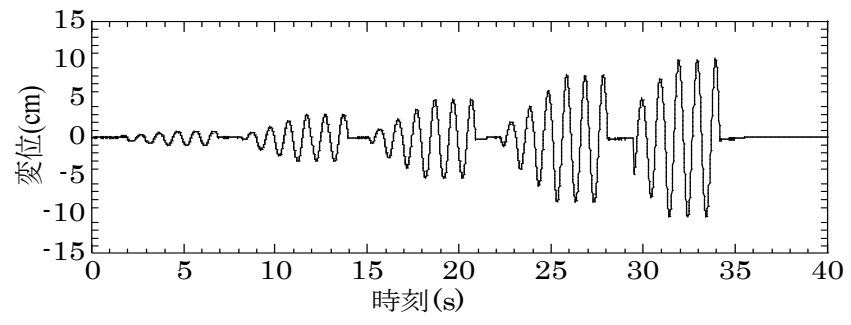

図 5 入力変位波形 


\section{4. 複合地盤材を用いた応答低減装置の復元力特性のモデル化}

\section{1. 復元力特性を決めるパラメータ}

図 8 に応答低減装置の $Q-d$ 関係を示す。この復元力特性に基づ いて履歴特性を表す数值モデルを設定した 8)。本モデルは初期剛性 $K 0$ 、降伏荷重 $F_{y} 、 2$ 次剛性比 $B$ 、除荷剛性比 $\alpha$ 、経験最大変位の増 大率 $\Phi$ の 5 つのパラメータによって規定し、原点を通る 3 次曲線 $\left(F=a u^{3}\right)$ と設定する。ここで、係数 $a$ は経験最大変位に増大率 $\Phi$ を 乗じた変位点を指向するように決定される。詳細な履歷則について、 以下に述べる。

(a)降伏荷重 $\left( \pm F_{y}\right)$ を超えない場合

降伏前の初期剛性部については、図 9 に示寸ように初期剛性 $K_{0}$ 上を進み、除荷する際は荷重 $F=0$ まで除荷剛性 $\alpha \cdot K_{0}$ で戻るように 設定した。ただし、除荷後、原点に向かうスリップ区間で変形方向 が反転した場合は、除荷剛性で初期剛性を目指す。

(b)降伏荷重 $\left( \pm F_{y}\right)$ を超える場合

降伏荷重 $F_{y}$ に達すると 2 次剛性 $B \cdot K_{0}$ で進み、除荷する際は荷重 $F=0$ まで除荷剛性で戻るように設定した。そして、原点に戻り反対 側に移行する際、降伏していない場合は初期剛性上を進み、降伏し ている場合は、図 10 のように経験最大変位 $u_{\max }$ に倍率 $\Phi$ を乗じた 変位である指向点を 3 次曲線が目指す。その後、指向点を超えると 2 次剛性に移行する。ただし、除荷後、原点に向かうスリップ区間 で変形方向が反転した場合は、以下のように進行する。

$(\mathrm{b}-1)$ 直前のサイクルが初期剛性から 2 次剛性を経ている場合 初期剛性または 2 次剛性を除荷剛性で目指寸。

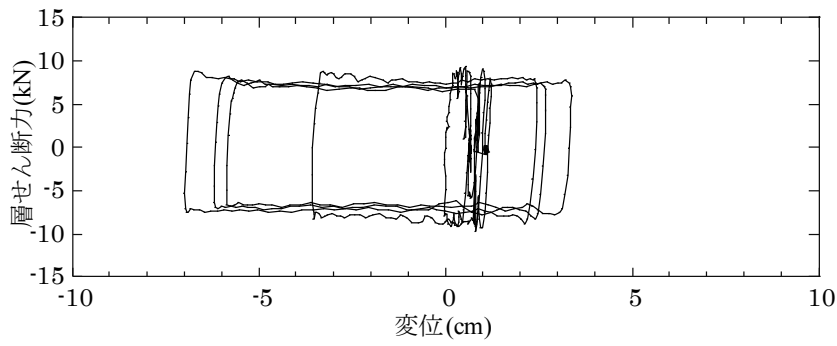

図 6 すべり支承の $Q-d$ 関係

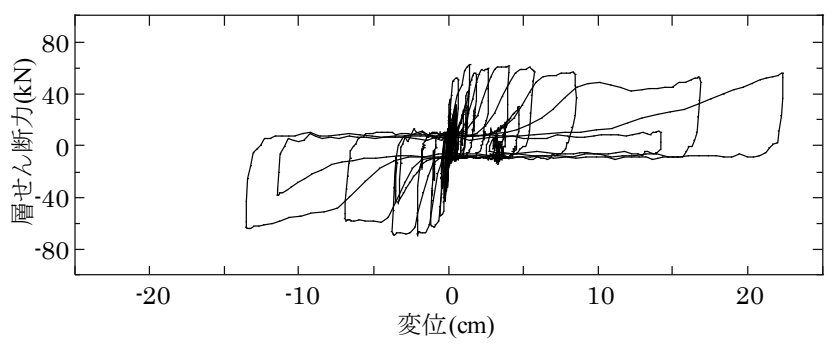

図 7 応答低減装置(シアキー埋込み)とすべり支承の $Q-d$ 関係

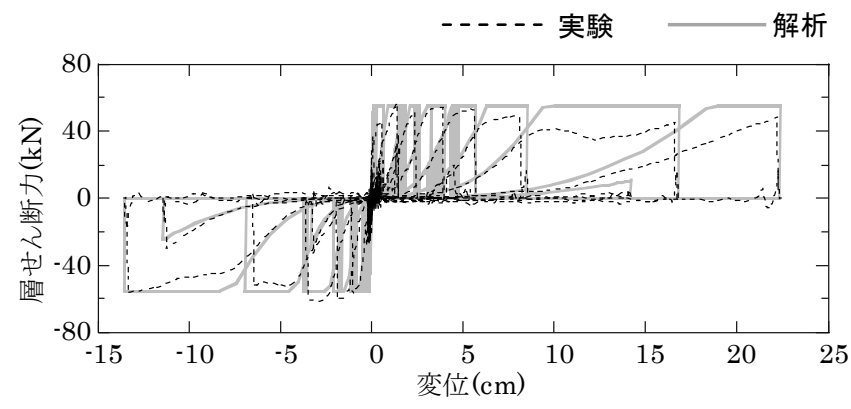

図 8 応答低減装置の $Q-d$ 関係 (b-2)直前のサイクルが 3 次曲線の場合 直前の 3 次曲線を除荷剛性で目指寸。

(b-3) 3 次曲線から 2 次剛性を経ている場合

直前の 3 次曲線または 2 次剛性を除荷剛性で目指す。

\section{2. 応答低減装置の復元カのシミュレーション}

実験結果より、2 次剛性比 $B=0$ 、除荷剛性比 $\alpha$ は初期剛性に対 し十分大きいものとし、表 3 のようにパラメータの值を決定した。 実験時の相対変位波形を入力して行った復元力特性のシミュレーシ ヨン結果を図 8 に示す。これより、変形が大きくなる場合で履歴ル ープをやや大きく評価していることに課題を残すが、提案した復元 力特性が応答低減装置の抵抗特性の規則的な挙動を概ね捉えている ことが確認できる。

\section{5. 戸建住宅を想定した質点系モデルによる地震応答解析}

\section{1. 上部構造モデル}

解析モデルとして、建物総重量 $714 \mathrm{kN}$ である鉄骨造 2 階建ての 戸建住宅 6)を想定した。設定した解析諸元を表 4 に示寸。この重量 に対して、住宅性能表示制度による耐震等級 2 相当の 1 層地震時層 せん断力に対応する耐力壁を設置した。履歴モデルは図 11 に示す ように標準トリリニア型とし、 2 階の耐力壁量も 1 階と同数とした。 このときの基礎固定状態を基準モデルとし、初期剛性に基づく 1 次 固有振動数は $2.3 \mathrm{~Hz}$ である。また、減衰定数は上部構造に非構造壁 を設置することを考慮し $5 \%$ とした。

\section{2. 応答低減装置のモデル化と解析ケース}

応答低減装置の復元力特性は、実験結果をもとに 4 章で述べたパ ラメータと履歴則を用いてモデル化した。すべり支承の復元力特性 は完全弾塑性モデルとし、降伏荷重は実験から得られた摩擦係数に 建物総重量を乗じた值とした。地震応答解析モデルは、図 12 のよ うに 3 質点の質点系モデルを用い、基礎部にす心゙り支承と応答低減 装置の抵抗特性モデルを取り付けた。
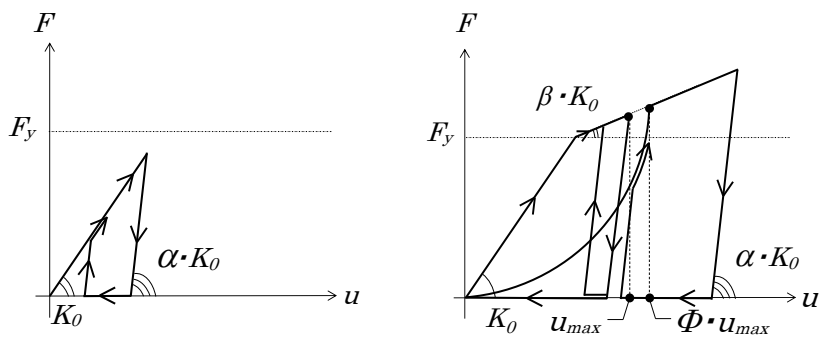

図 9 降伏前の初期剛性 図 103 次曲線が指向する降伏点变位

表 3 復元力特性のパラメータ

\begin{tabular}{|c|c|c|c|c|}
\hline$K_{0}(\mathrm{kN} / \mathrm{cm})$ & $F_{y}(\mathrm{kN})$ & $\beta$ & $\alpha$ & $\Phi$ \\
\hline 50 & 55 & 0.0 & 100 & 1.1 \\
\hline
\end{tabular}

表 4 解析諸元

\begin{tabular}{|c|c|c|}
\hline 層 & $\begin{array}{c}\text { 重量 } \\
(\mathrm{kN})\end{array}$ & $\begin{array}{c}\text { 階高 } \\
(\mathrm{mm})\end{array}$ \\
\hline $2(\mathrm{RF})$ & 182 & 2870 \\
\hline $1(2 \mathrm{~F})$ & 221 & 2870 \\
\hline 基礎梁 & 311 & \\
\hline
\end{tabular}

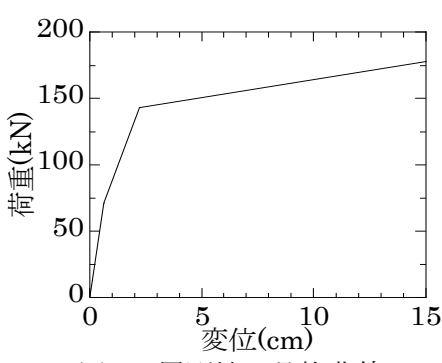

図 11 層剛性の骨格曲線 
解析対象は、耐震等級 2 相当の基準モデルと、上部構造に制震ダ ンパーを用いて減衰機構を付加した耐震性能向上モデル(基準モデ ル+制震ダンパー)の 2 ケースである。制震ダンパーは、荷重一変位 関係にバイリニア型復元力をもつ履歴型ダンパーをモデル化し、図 13 に 1 枚当たりの荷重一変位関係を示す。このような履歷特性を有 する減衰機構を 1 層のみに配置した。

また、応答低減装置を用いた解析では、 2.2 節で述べたシアキー を複合材料に埋込んだシアキー埋込みタイプ(図 14) と、シアキーと 複合地盤材との間にスリップ距離 $5 \mathrm{~cm}$ を設けたスリップタイプ(図 15)の 2 ケースである。スリップタイプはあるレベル以下の地震動に はすべり支承のみで抵抗し、それ以上の地震動レベルに対してはす べり支承と複合材で抵抗する。

\section{3. 入力地震動}

入力地震動は、最大速度を 50kine に基準化した El centro 1940-NS、Taft 1952-EW、Hachinohe-1968-EW の 3 波に加え、 BCJ-L2 と告示波(乱数位相、神戸位相)の極稀地震動の 6 波をレベ ル 2 相当の地震動とした。さらに、これらの設計用地震動を大きく 上回る極大地震として、観測波である 1995 年兵庫県南部地震での JMA 神戸と、2016 年熊本地震での KiK-net 益城の 2 波の地震動に ついて検討した。解析の時間間隔は 0.001 秒刻みとした。それぞれ の最大加速度と最大速度を表 5 に示寸。また、各地震動の加速度応 答スペクトル $(\mathrm{h}=5 \%)$ を図 16 に示す。

\section{4. 応答目標値}

上記のレベル 2 相当地震と極大地震に対する応答目標值を、表 6 に示す。レベル 2 相当地震に対しては、最大層間変形角を $1 / 100 \mathrm{rad}$. 以内に抑えることを目標とし、基礎部の相対変位は隣接する建物と のクリアランスや配管の許容変位を考えて $30 \mathrm{~cm}$ 以内とした。極大 地震に対しては、最大層間変形角を建物の再使用が可能となる範囲 である 1/40rad. 以内、最大基礎変位は、レベル 2 相当と同じ $30 \mathrm{~cm}$ 以内に抑えることを目標とした。

\section{5. レベル 2 相当地震に対する応答解析結果と考察}

応答解析は、基礎固定モデル( $\square)$ とそこに制震ダンパーを付加し たモデル(苗)に加え、制震ダンパーを付加しない建物にシアキー埋 込みタイプの装置を 1 個設置したモデル $(\triangle)$ 、スリップタイプの装 置を 1 個設置したモデル $(\boldsymbol{\Delta})$ について行った。レベル 2 相当地震の 各入力地震動について、図 17 に基礎相対変位 -1 層層間変位の最大 值を示し、また、図 18 に基礎加速度 -1 層加速度の最大值を示す。 なお、図 18 中の基礎固定は、制震ダンパーを設置した基礎固定モ デルの結果である。

図 17 より、基礎固定モデル( $\square$ )の場合は入力地震動の最大加速度 が大きくなるにつれて最大層間変位が大きくなり、Hachinohe 以外 の 5 波においてレベル 2 相当地震に対する目標値 $(2.78 \mathrm{~cm})$ を超える。 このモデルに制震ダンパーを付加したモデル(ם)では、いずれの地 震動でも最大層間変位は低減され制震効果が確認できるが、応答低 減装置を設置することにより、さらに最大層間変位が低減し 1/200rad.以下に抑えられていることがわかる。これは、複合材料の 剛性と勒性的な抵抗特性による効果で、最大基礎変位、層間変位と もに目標値を満たすことが確認できる。次に、装置をそれぞれ 1 個 用いたシアキー埋込みタイプ $(\triangle)$ とスリップタイプ(ム)の応答を比 較すると、2つのタイプで大きな差はないことがわかる。
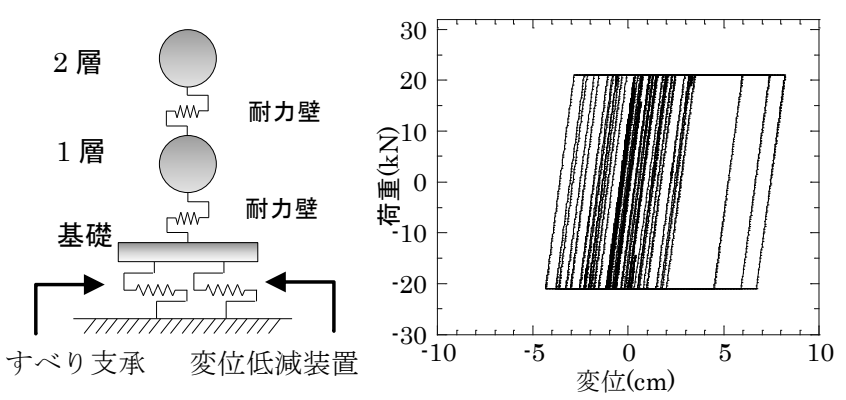

図 13 履歴型ダンパーの

図 12 解析モデル

荷重一変位関係

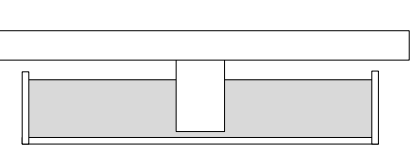

図 14 シアキー埋込みタイプ

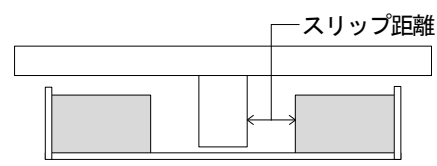

図 15 スリップタイプ

表 5 入力地震動一覧

\begin{tabular}{|c|c|c|c|}
\hline \multicolumn{2}{|c|}{ 入力地震動 } & $\mathrm{A}_{\max }(\mathrm{Gal})$ & $\mathrm{V}_{\max }(\mathrm{kine})$ \\
\hline \hline \multirow{4}{*}{$\begin{array}{c}\text { レ } \\
\text { ル } \\
2\end{array}$} & El centro 1940-NS & 510.0 & 50.0 \\
\cline { 2 - 4 } & Taft 1952-EW & 496.9 & 50.0 \\
\cline { 2 - 4 } & Hachinohe-1968-EW & 238.4 & 50.0 \\
\cline { 2 - 4 } & BCJ-L2 & 355.7 & 57.4 \\
\cline { 2 - 4 } & 告示波 JMA 神戸位相 & 395 & 56.4 \\
\cline { 2 - 4 } & 告示波 乱数位相 & 365 & 59.6 \\
\hline \hline \multirow{2}{*}{ 極 } & JMA 神戸-NS & 820.6 & 91.0 \\
\cline { 2 - 4 } & KiK-net 益城-EW & 1156.9 & 134.5 \\
\hline
\end{tabular}

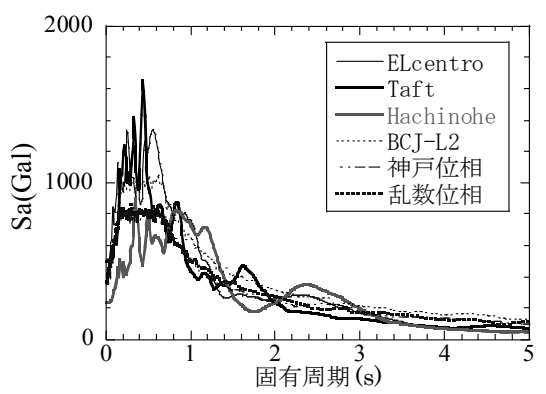

(a) El centro - Taft · Hachinohe · BCJ · 神戸位相 · 乱数位相

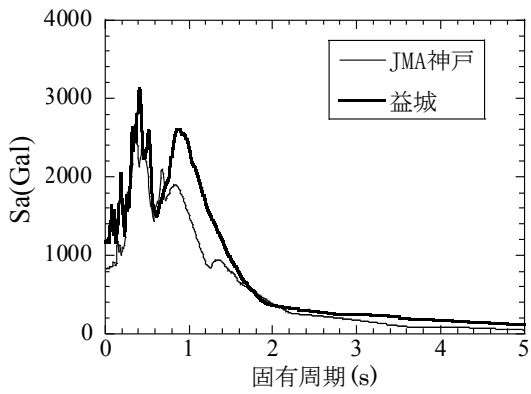

(b) JMA 神戸 - KiK-net 益城

図 16 入力地震動の加速度応答スペクトル $(h=5 \%)$

\section{表 6 応答目標値}

\begin{tabular}{|c|c|c|}
\hline 入力地震動 & $\begin{array}{c}\text { 基礎部 } \\
\text { 最大相対変位 }\end{array}$ & $\begin{array}{c}\text { 上部架構 } \\
\text { 最大層間変位 }\end{array}$ \\
\hline レベル 2 地震 & $30 \mathrm{~cm}$ 以下 & $1 / 100 \mathrm{rad}(2.78 \mathrm{~cm})$ 以下 \\
\hline 極大地震 & $30 \mathrm{~cm}$ 以下 & $1 / 40 \mathrm{rad}(6.95 \mathrm{~cm})$ 以下 \\
\hline
\end{tabular}


また、図 18 に示寸加速度応答については、装置のタイプにかか わらず基礎と 1 層の応答加速度が、制震ダンパー付き基礎固定モデ ルに比べ低減している。特に 1 層加速度の応答低減に効果が見られ、 $250 \mathrm{gal}$ 程度まで小さくなっている。さらに、両装置を用いた場合の 基礎の残留変位について表 7 に示す。すべり支承のみに比べ、大幅 に残留変位が小さくなる地震動があることがわかる。また、埋込み タイプでは、スリップタイプに比べ残量変位が小さくなる傾向にあ り、最大でも $2.7 \mathrm{~cm}$ 程度に留まることがわかる。
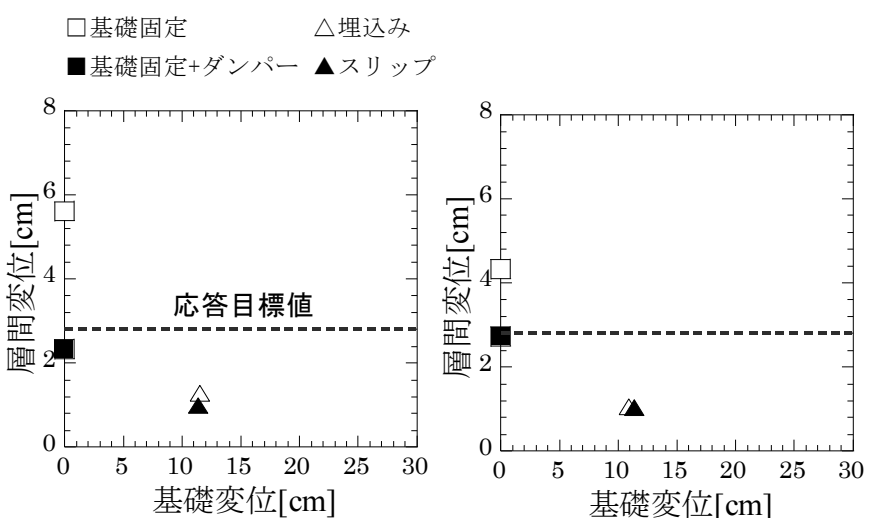

(a)El centro

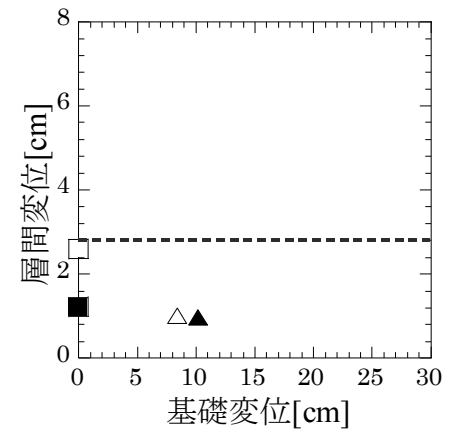

(c)Hachinohe

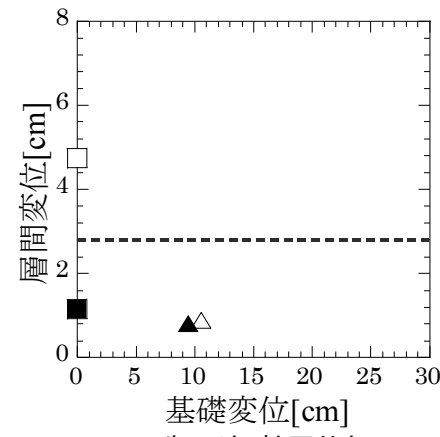

(e) 告示波 神戸位相

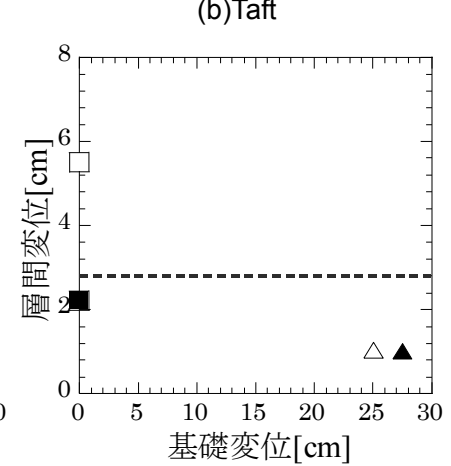

(d) BCJ-L2

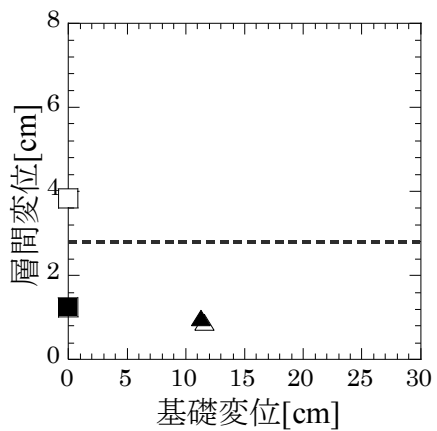

(f) 告示波 乱数位相

図 17 最大基礎相対変位一最大層間変位(レベル 2 相当地震)

表 7 基礎の残留変位 $(\mathrm{cm})$

\begin{tabular}{|c|c|c|c|}
\hline & $\begin{array}{c}\text { すベり支承 } \\
\text { のみ }\end{array}$ & 埋込み & スリップ \\
\hline El centro & 14.8 & 1.59 & 3.44 \\
\hline Taft & 0.82 & 1.06 & 3.07 \\
\hline Hachinohe & 3.59 & 1.48 & 0.36 \\
\hline BCJ - L2 & 51.9 & 2.00 & 5.42 \\
\hline 告示波 JMA 神戸位相 & 7.01 & 0.78 & 2.33 \\
\hline 告示波 乱数位相 & 6.51 & 2.69 & 4.84 \\
\hline
\end{tabular}

次に、図 19 に 1 層加速度、図 20 に基礎変位の時刻歴波形を示す。 装置を用いると、基礎固定モデルに比べて加速度が小さくなってい ることがわかる。スリップタイプの装置において基礎変位が $5 \mathrm{~cm}$ を 超える際、シアキーと地盤の衝突が起こるが、地盤の剛性が低いた め、1 層の加速度応答は埋め込みタイプとほとんど変わらない。

図 21 における応答低減装置の復元力特性は、 4 章で示した履歴則 に従って履歴ループを描いていることが確認できる。

\section{6. 極大地震に対する応答結果}

\section{1. 極大地震への対応を考えた上部構造モデル}

5 章で用いた戸建住宅モデルに、極大地震の観測波(JMA 神戸波・ 益城波)を入力したときの装置の効果について検討する。応答目標值 は表 6 に示した極大地震に対するものである。極大地震においては、 基礎部の抵抗剛性が大きくなることで 1 層層間変位が大きくなるこ とを抑えるため、応答低減装置を設置したモデルにも制震ダンパー

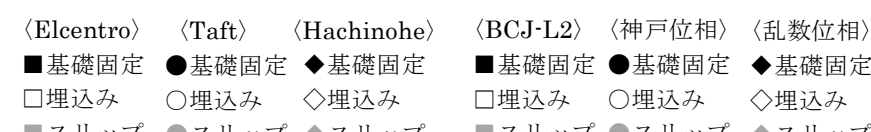

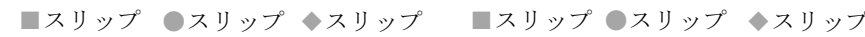
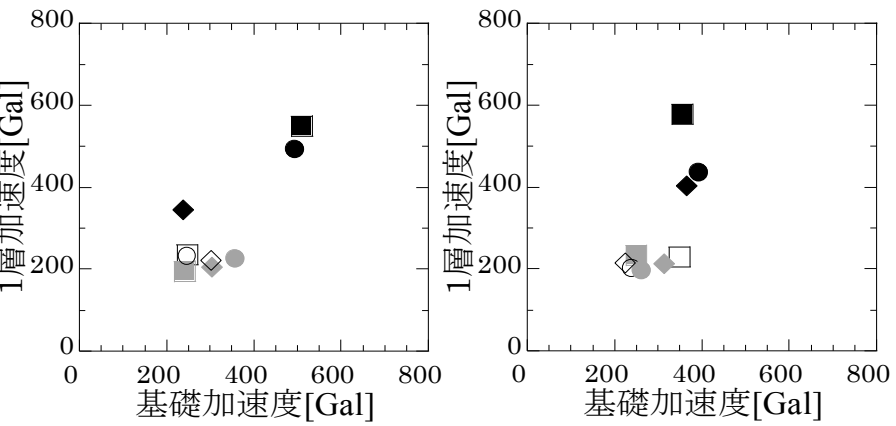

(a)El centro - Taft - Hachinohe (b) BCJ - 告示波神戸 - 乱数位相 図 18 最大基礎加速度 -1 層加速度 (レベル 2 相当地震)

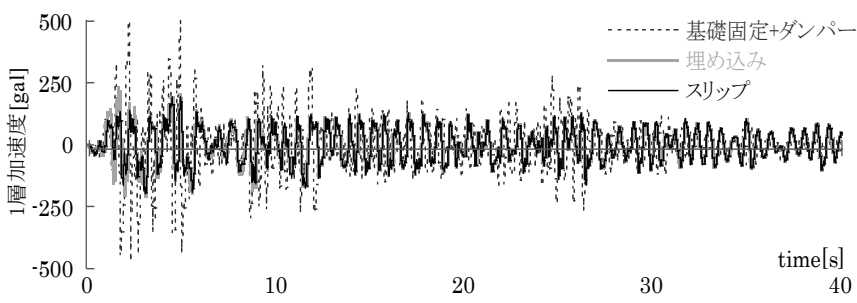

図 191 層加速度の時刻歴波形

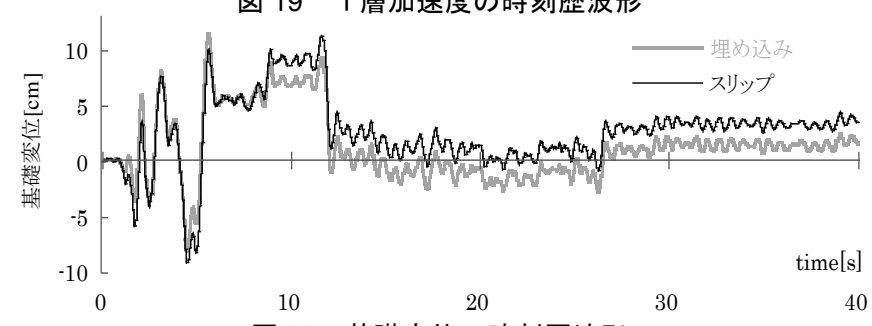

図 20 基礎変位の時刻歴波形

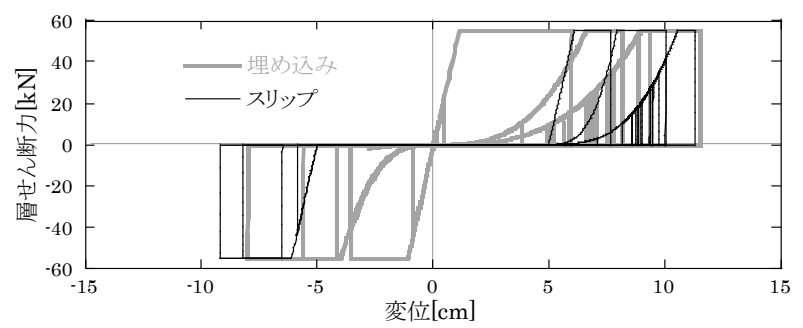

図 21 応答低減装置の Q-d 関係 
を併用している。装置の個数が 1 個の場合と、基礎変位を抑制する ために 2 個に増やした場合の解析を行った。

\section{2. 極大地震に対する応答解析結果と考察}

図 19 に、極大地震の各入力地震動について基礎変位 -1 層層間変 位の最大值を示す。基礎固定モデルでは、JMA 神戸波、益城波とも に制震ダンパーを付加した場合でも層間変形が過大となる。装置を 1 個取り付けたモデルでは、益城波で目標值の $30 \mathrm{~cm}$ を上回ってい るが、最大層間変位は大幅に低減し、1/200 rad.以内に抑えられてい る。また、装置の個数を 2 個に増やすことで最大基䃈変位が $10 \mathrm{~cm}$ ほど低減し、応答目標值に近くなる。

また、基礎と 1 層の最大加速度を示した図 20 より、応答低減装 置の効果により応答加速度が $1 / 2$ 以下まで小さくなることがわかる。 表 8 に示寸基礎の残留変位については、益城波で装置を用いること で $10 \mathrm{~cm}$ 程度まで変位が抑えられている。

\section{7.まとめ}

本研究では、戸建住宅の地震応答低減を目的として複合地盤材を 用いた装置を開発し、その抵抗特性を大型の振動台実験により把握 した。さらに応答低減装置の抵抗特性とす心゙り支承をモデル化した 戸建住宅の地震応答解析により、レベル 2 相当地震および極大地震 における応答低減効果について検討した。

以下に、本研究の結果をまとめて示す。

1）戸建住宅用の応答低減装置を開発し、その抵抗特性を振動台実験 により確認した結果、複合地盤材の繰り返し荷重に対する勒性的な 特性が、基礎変位や上部構造加速度の低減に効果的であることがわ かった。

2）レベル 2 相当の 6 つの地震動を用いて、鉄骨造の戸建住宅を想定 した質点系モデルによる地震応答解析を行った。その結果、制震ダ ンパーを設置した基礎固定モデルと比較して、応答低減装置を用い ることで、上部建物の最大層間変位や加速度の応答を低減できるこ とを示した。また、基礎との最大相対変形や残留変形も許容できる 值であることを確認した。

3）レベル 2 地震動を上回る極大地震に対しては、制震ダンパーを設 置した上部建物に応答低減装置の個数を増や寸ことで、上部建物の 最大層間変位や加速度の応答低減に効果が大きいことがわかった。 ただし、基礎の最大相対変位や残留変形が大きくなることへの対策 は今後の課題である。

謝辞

本研究では、防災科学技術研究所の強震動観測網 KiK-net を使用 致しました。また、応答解析ソフトの作成にあたり、ユニオンシス テム(株)の山崎久雄氏に協力を頂きました。ここに謝意を表します。

\section{参考文献}

1）飯場正紀，小豆畑達哉，井上波彦，平野茂：2011 年東北地方太平洋沖地 震における戸建免震住宅の地震時挙動，その 2 宮城県内の戸建免震住宅の 調査および変位応答と近傍地震動の関係, 日本建築学会大会学術講演梗概集, 構造 II , pp.513-514，2012.9

2）桐山伸一, 中田信治, 花井勉, 福和伸夫 : 実大振動実験による戸建て免震 住宅装置別応答性状比較，日本建築学会構造工学論文集，Vol.50B，2004.3

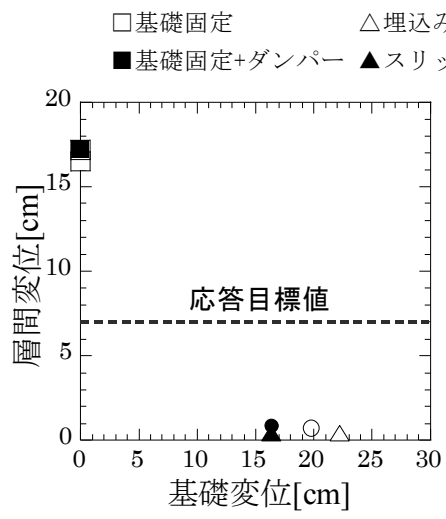

(a)JMA 神戸
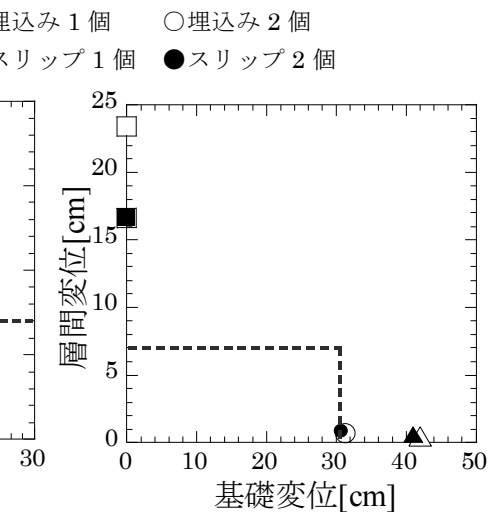

(b)益城
図 22 最大基礎相対変位一最大層間変位(極大地震)

表 8 基礎の残留変位 $(\mathrm{cm})$

\begin{tabular}{|c|c|c|c|}
\hline & $\begin{array}{c}\text { すベり支承 } \\
\text { のみ }\end{array}$ & 埋込み 2 個 & スリップ 2 個 \\
\hline JMA 神戸 & 3.83 & 3.82 & 5.10 \\
\hline 益城 & 42.2 & 11.3 & 10.8 \\
\hline
\end{tabular}

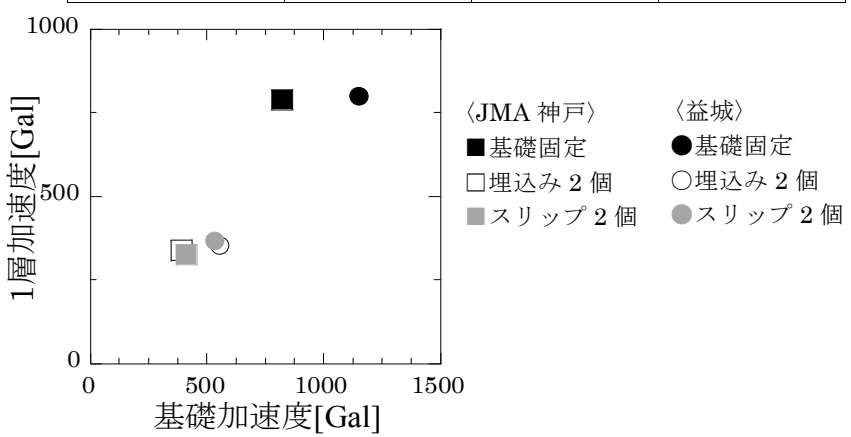

図 23 最大基礎加速度 -1 層加速度(極大地震)

3）飯場正紀，花井勉ほか：変位抑制部材を用いた免震層衝突時における免震 住宅の地震時応答, その 1 変位抑制部材を用いた免震モデルの振動台実験と 解析, その 2 免震層衝突時における免震住宅の地震時安全性, 日本建築学会 大会学術講演梗概集, 構造 II , pp.425-428, 2004.8

4）高橋武宏, 天埜貴仁, 福和伸夫 : 実大震動実験に基づく戸建免震住宅の免 震層変形抑制に関する研究, 日本建築学会構造系論文集, 第 699 号, pp.565-574, 2014.5

5）中田信治, 花井勉ほか : 変位抑制部材を有する戸建て免震住宅の地震時安 全性について, その 1 変位抑制部材作動時の応答解析, その 2 変位抑制部材 の効果とその設計法の提案, 日本建築学会大会学術講演梗概集, 構造 II, pp.1001-1004, 2007.8

6）島村淳, 岸本美季, 柏尚稔, 宮本裕司 : ゴムチップと繊維材を用いた複合 地盤材料の力学特性に関する研究, 日本建築学会技術報告集, 第 17 巻, 第 35 号, pp.61-66, 2011.2

7）宮本裕司，島村淳，藤井達，星澤府美子，柏尚稔 : 基礎底面の絶縁と複合 改良地盤の埋込み効果による地震応答低減に関する基礎的研究, 日本建築学 会構造系論文集，第 691 号, pp.1559-1567, 2013.9

8）星澤府美子, 深谷伸作, 宮本裕司, 中田信治, 島村淳, 三宅辰哉 : 戸建住 宅用変位制御機構の開発とその地震応答低減効果, 日本建築学会学術梗概集, 構造 II , pp.523-526, 2014.9

[2016 年 10 月 5 日原稿受理 2016 年 11 月 22 日採用決定］ 